УДК 37.376

DOI: $10.15330 /$ esu.1.19-23
Олександр Кучай,

доктор педагогічних наук, доцент,

Національний університет біоресурсів i

природокористування України (м. Київ, Україна)

Olexandr Kuchai,

Doctor of pedagogical sciences, Associate Professor, National University of Life and Environmental

Sciences of Ukraine (Kyiv, Ukraine)

kuchay@ukr.net

\section{Василь Шинкарук,}

доктор філологічних наук, професор,

Національний університет біоресурсів i

природокористування України (м. Київ, Україна)

Vasyl Shynkaruk,

Doctor of philology, Professor,

National University of Life and Environmental

Sciences of Ukraine (Kyiv, Ukraine)

vashyn2010@ukr.net

\section{Олена Біда,}

доктор педагогічних наук, професор,

Закарпатський угорський інститут ім. Ференца

Ракоці II (м. Берегово, Україна)

Olena Bida,

Doctor of pedagogical sciences, Professor,

Ferenc Rakoczi II Transcarpathian Hungarian Institute (Beregovo, Ukraine)

tetyanna@ukr.net

Тетяна Кучай, доктор педагогічних наук, доцент,

Закарпатський угорський інститут ім. Ференца Ракоці II (м. Берегово, Україна)

\section{Tetiana Kuchai,}

Doctor of pedagogical sciences, Associate Professor, Transcarpathian Hungarian Institute. Ferenc Rakoki II (Berehove, Ukraine)

tetyanna@ukr.net

\title{
СУЧАСНИЙ СТАН ІНКЛЮЗИВНОЇ ОСВІТИ В КРАЇНАХ ЄВРОПЕЙСЬКОГО СОЮЗУ
}

\section{THE CURRENT STATE OF INCLUSIVE EDUCATION IN THE EUROPEAN UNION}

У статті розглядається проблема інклюзивної освіти в сучасному освітньому просторі. Головною метою інклюзивного навчания с усунення будь-якої дискриміначії в освітньому прочесі, забезпечення доступності освіти для всіх, то досягнення иієї мети може бути організовано по-різному, ио й спостерігасться в освітніх системах різих країн. Висвітлено завдання, що потребують впливу з боку системи державного управління освітою иуодо організачій навчання дітей з особливими потребами.

Ключові слова: інклюзивне навчання, навчання дітей, особливі потреби, різні крайни.

The article deals with the problem of inclusive education in the modern educational space. The main purpose of inclusive learning is to eliminate any discrimination in the educational process, to make education accessible to all, and the achievement of this goal can be organized differently, as is the case in the educational systems of different countries. The tasks that need 
influence from the system of public administration of education on organization of education of children with special needs are highlighted.

Today, it is necessary to move towards the implementation of international practice to increase the number of general education institutions ready to provide educational services to children with special needs. In solving complex and multifaceted tasks of inclusive education, an important role is assigned to the teacher, because it directs the educational process, systematizes, specifies the content of cognitive material, looks for the most rational ways to master the skills necessary for self-care, necessary for self-care opportunities for personal disclosure of each child.

Adequate training for educators to work with children with special needs should be a key factor in promoting inclusive education. Today, the problem is the question of a teacher who would understand the specific problems of such children. The result will be satisfactory only if, together with the tutors, the same team will work with the relevant specialists - rehabilitation teachers, speech therapists, practical psychologists, social pedagogues, doctors, etc. Working in groups with an inclusive form of education gives a qualitatively new impetus to the teacher's self-improvement, as he has the opportunity to deepen his knowledge about the laws of children's development, to develop his own positions on the effectiveness of educational technologies. This work forms in the teacher a new understanding of the problems of children who are lagging behind, exposes to him the strategy and tactics of psychological and pedagogical support of these children.

Key words: inclusive education, children's education, special needs, different countries.

Постановка проблеми у загальному вигляді та іiі зв'язок із важливими науковими чи практичними завданнями. Проблема інклюзивної освіти в сучасному українському освітньому просторі набуває особливої ваги 3 огляду на те, що інтегрування осіб $з$ особливими потребами в соціокультурне й загальноосвітнє середовище $\epsilon$ сьогодні надзвичайно актуальним. Недостатня розробленість цієї педагогічної проблеми, збільшення кількості дітей з порушеннями психофізичного розвитку, котрі не мають змоги отримувати психолого-педагогічну підтримку та корекційно-реабілітаційну допомогу, недостатній рівень культури та освіченості педагогів та батьків, брак елементарної матеріальної бази, низький фінансовий стан сімей, незадовільне навчально-методичне забезпечення (навчальні програми, посібники, підручники, методичні вказівки тощо) зумовлюють процеси переосмислення суспільством ставлення до осіб з особливими потребами.

У різних країнах світу інклюзію розглядають як процес визнання і реагування на різноманіття потреб усіх тих, хто навчається, і дає їм змогу брати активну участь у процесі отримання знань у культурному і суспільному житті. Розглядаючи сучасні матеріали досліджень українських i зарубіжних науковців, виявили, що інклюзія створює сприятливі умови для рівної участі людей з особливими освітніми потребами (фізичними, психічними, соціальними, емоційними) в загальній системі освіти, для індивідуального вибору та отримання спеціальних послуг, а також адаптації, реабілітації і соціалізації тих, хто цього потребує. У межах інклюзивної моделі, 3 залученням усіх школярів до всіх напрямів навчання та шкільного життя, незалежно від індивідуальних особливостей чи відмінностей, - всі учні навчаються разом у звичайних школах, класах, активно адаптуючись та змінюючись. Спеціальній освіті сьогодні необхідні зміни і модифікація змісту, структури, якості, технологій, підходів і стратегій у контексті інклюзії з урахуванням потреб усіх дітей, котрі прагнуть навчатися.

На сучасному етапі ідея освітньої інклюзії набуває змістовного значення i перетворюється на важливу проблему сучасних науково-педагогічних досліджень. Вона поєднує в собі поняття комплексності, предметності, системності та визначається науковцями і фахівцями-практиками як модель організації процесу спеціальної освіти в умовах загальноосвітньої школи. На початку XXI століття 
практика педагогічної діяльності на інклюзивній основі набуває певного розвитку, оскільки на думку багатьох учених найвищим щаблем інтеграційних процесів в освітньому просторі $є$ інклюзивна освіта, що нині визначається як найпопулярніший i найважливіший інноваційний освітній рух. Зважаючи на реформування сучасної освітньої галузі, ця проблема набуває сьогодні особливої ваги та актуальності [1].

Метою статті $\epsilon$ розкрити сучасний стан інклюзивної освіти в країнах Свропейського Союзу.

Аналіз останніх досліджень і публікацій, в яких започатковано розв'язання порушеної проблеми і на які спирається автор. Питанням інклюзивного навчання у закладах вищої освіти займалися такі вчені: Н. Бастун, С. Богданова, I. Звєрєва, І. Срмаков П. Таланчук, Г. Оникович, І. Іванова, Р. Кравченко, Н. Софій, М. Томчук, Елен Р. Даніелс, Кей Стаффорд та інші).

Виклад основного матеріалу дослідження 3 повним обгрунтуванням одержаних наукових результатів. Система інклюзивної освіти України проходить фазу становлення. Її подальший розвиток залежить від принципів державної політики, яка, у свою чергу, повинна спиратися на можливості державного та місцевих бюджетів. Підходи до надання освітніх послуг для дітей 3 особливими потребами, що використовуються в Україні, сформовані за радянських часів. Вони передбачають навчання таких дітей у спеціальних закладах, що призводить до глибокої сегрегації суспільства та виключає їх з активного соціального життя.

У Свропі кількість дітей з особливими освітніми потребами становить 15 млн. Такі діти здебільшого закінчують середню школу з невисоким рівнем кваліфікації і достатньо часто стають безробітними або не є економічно активними. Якщо ці діти не мають достатнього рівня підтримки в освітніх закладах, їхній розвиток буде повільним, а родини піддаватимуться значному навантаженню. Система інклюзивної освіти в багатьох країнах ЄС формується на основі конщепщії, сформульованої Т. Бутом. Цей учений визначав, що інклюзивна освіта $є$ процесом розширення участі та зменшення виключення з культури, навчальних програм та суспільства загальноосвітніх шкіл, у яких навчаються діти з ООП [2].

Дослідження досвіду навчання дітей та молоді з особливостями психофізичного роз витку в країнах Свропи свідчить, що у переважній більшості інклюзивне навчання є основною формою здобуття освіти людьми з обмеженими можливостями. Однак варто зазначити, що діти з особливими освітніми потребами мають змогу здобувати освіту й у спеціальних навчальних закладах, й у закладах масового типу. Сучасний світовий освітній процес відрізняється, 3 одного боку, варіативністю систем освіти, їх структурою, визначенням шляхів вирішення конкретних завдань. 3 іншого боку, у ньому простежується низка загальних тенденцій, однією 3 яких $є$ реалізація інклюзивної освіти. Оскільки головною метою інклюзивного навчання $є$ усунення будь-якої дискримінації в освітньому процесі, забезпечення доступності освіти для всіх, то досягнення цієї мети може бути організовано по-різному, що й спостерігається в освітніх системах різних країн [3].

У європейській практиці існує кілька моделей реалізації освітньої політики навчання дітей $з$ особливими потребами, які спрямовані на подолання зазначених загроз. Результати аналізу досвіду впровадження інклюзивної освіти в розвинутих країнах Свропи дають можливість стверджувати, що у європейських країнах спеціальні заклади освіти функціонують і надають допомогу дітям з обмеженими можливостями здоров'я, однак вони не $\epsilon$ сегрегативними осередками. "Кордони" між спеціальною та загальною освітою прозорі, неявні, країни 3 демократичним устроєм 
пропагують цінності громадянського суспільства, ідеї рівноправ'я, толерантності та інклюзії. Освітнє законодавство європейських країн визнає право батьків на вибір навчального закладу для своєї дитини, регламентує функціонування спеціальних та інклюзивних закладів. На сьогодні у Європі відбувається різке скорочення спеціальних закладів як за кількістю, так і за видами спеціалізації, спостерігається тенденція до повного переходу на навчання дітей з особливостями розвитку в інклюзивних закладах.

Аналіз європейських моделей інклюзивної освіти доводить наявність великого позитивного досвіду, який потрібно адаптувати для впровадження в Україні. Дослідники називають такі завдання, що потребують впливу з боку системи державного управління освітою щодо організації навчання дітей з особливими потребами:

- нормативно-правове регулювання процесу запровадження інклюзивної форми навчання;

- оновлення вимог щодо матеріально-технічного забезпечення загальноосвітнього навчального закладу, де реалізується інклюзивне навчання; пристосування навчально-виховного процесу до потреб дітей, у тому числі й з особливостями розвитку;

- налагодження специфічного психолого-медико-педагогічного супроводу дітей 3 особливими освітніми потребами, які навчаються у загальноосвітніх навчальних закладах;

- особливості співпраці 3 батьками, які виховують дітей 3 особливостями психофізичного розвитку [4].

Конщепція інклюзивної освіти відображає одну з головних демократичних ідей усі діти є цінними й активними членами суспільства. В їі основі лежить принцип дотримання прав дитини на здобуття якісної освіти. Філософія інклюзивної освіти базується на переконаннях у необхідності зміни освітньої парадигми - реформуванні шляхом об'єднання двох традиційних систем (спеціальної і масової освіти) в єдину освітню систему. При підготовці майбутніх спеціалістів до роботи в загальноосвітньому навчальному закладі слід акцентувати їхню увагу на те, що у школі інклюзія не відбувається лише за рахунок переведення дитини до звичайного класу, це радше бажаний кінщевий результат.

Висновки представленого у статті дослідження і перспективи подальших наукових розвідок із зазначеного напряму. Сьогодення вимагає рухатися у напряму втілення міжнародної практики щодо збільшення кількості загальноосвітніх навчальних закладів, готових до надання освітніх послуг дітям з особливими потребами. У розв'язанні складних і багатопланових завдань інклюзивної освіти важлива роль відводиться педагогові, оскільки саме він спрямовує навчально-виховний процес, систематизує, конкретизує зміст пізнавального матеріалу, вишукує найбільш раціональні шляхи щодо оволодіння дітьми уміннями, необхідними в самостійному пізнанні, формує необхідні навички, забезпечуючи можливості особистісного розкриття кожної дитини.

Ключовим фактором сприяння інклюзивній освіті має бути відповідна підготовка педагогів для роботи з дітьми з особливими потребами. На сьогодні проблемним є питання щодо педагога, який розумівся $б$ на специфічних проблемах таких дітей. Результат буде задовільним лише тоді, коли разом 3 вихователями в одній команді працюватимуть і відповідні спеціалісти - вчителі-реабілітологи, вчителілогопеди, практичні психологи, соціальні педагоги, лікарі тощо. Робота в групах 3 інклюзивною формою навчання дає якісно новий стимул до самовдосконалення педагога, тому що він має можливість поглиблювати свої знання про закономірності розвитку дітей, виробляти власні позиції щодо ефективності навчальних технологій. 
Ця робота формує у педагога нове розуміння проблем дітей, які відстають, розкриває перед ним стратегію і тактику психолого-педагогічної підтримки цих дітей [5].

1. Швед М. Основи інклюзивної освіти: підручник. - Львів: Український католицький університет, 2015. - $360 \mathrm{c}$.

2. Кузнєцов К. Удосконалення механізмів державного управління у фінансуванні системи інклюзивної освіти \І Державне управління та місцеве самоврядування, 2018, вип. 2(37). С 7888.

3. Продіус О.І. Особливості моделей інклюзивної освіти в країнах Свропи відповідно до вимог сучасного суспільства. URL: http://psae-jrnl.nau.in.ua/journal/4_72_2_2019_ukr/12.pdf

4. Лукіна Т., Шошова А. Реалізація державної освітньої політики щодо дітей з особливими освітніми потребами: зарубіжні підходи. URL: http://lib.iitta.gov.ua/714558/1/apdyo_ 2014_3_23.pdf

5. Інклюзивна освіта URL: https://vseosvita.ua/library/lekcia-z-osnov-inkluzivnogo-navcanna120652.html

\section{References}

1. Shved M. Osnovy inklyuzyvnoyi osvity: pidruchnyk. - Lviv: Ukrayinskyy katolytskyy universytet, 2015. $-360 \mathrm{~s}$.

2. Kuznyetsov K. Udoskonalennya mekhanizmiv derzhavnoho upravlinnya u finansuvanni systemy inklyuzyvnoyi osvity II Derzhavne upravlinnya ta mistseve samovryaduvannya, 2018, vyp. 2(37). S 78-88.

3. Prodius O.I. Osoblyvosti modeley inklyuzyvnoyi osvity v krayinakh yevropy vidpovidno do vymoh suchasnoho suspilstva. URL: http://psae-jrnl.nau.in.ua/journal/4_72_2_2019_ukr/12.pdf

4. Lukina T., Shoshova A. Realizatsiya derzhavnoyi osvitnoyi polityky shchodo ditey z osoblyvymy osvitnimy potrebamy: zarubizhni pidkhody. URL: http://lib.iitta.gov.ua/714558/1/ apdyo_2014_3_23.pdf

5. Inklyuzyvna osvita URL: https://vseosvita.ua/library/lekcia-z-osnov-inkluzivnogo-navcanna120652.html

Одержано статтю: 2.10.2019

Прийнято до друку: 16.10.2019

УДК 37:27-725-46

DOI: $10.15330 /$ esu. $1.23-30$

\section{Наталія Мукан,}

доктор педагогічних наук, професор,

Національний університет "Львівська політехніка" (м. Львів, Україна)

Nataliia Mukan,

Doctor of pedagogical sciences, Professor,

Lviv Polytechnic National University (Lviv Ukraine)

nataliya.v.mukan@lpnu.ua

\section{Оксана Блавт,}

доктор педагогічних наук, доцент,

Національний університет “Львівська політехніка" (м. Львів, Україна)

\section{Oksana Blavt,}

Doctor of pedagogical sciences, Associate Professor Lviv Polytechnic National University (Lviv Ukraine) oksanablavt@ukr.net

\section{ПАСТИРСЬКА ПЕДАГОГІКА: ПОТРЕБА СУСПІЛЬСТВА}

\section{PASTORAL PEDAGOGICS: THE NEED OF SOCIETY}

У статті розглянуто питания доцільності пастирської педагогіки. За результатами аналізу установлено, що такий вид педагогіки підтримуе суспільство й 